\title{
Electrochemical Organic Synthesis of Electron-Rich Biaryl Scaffolds: An Update
}

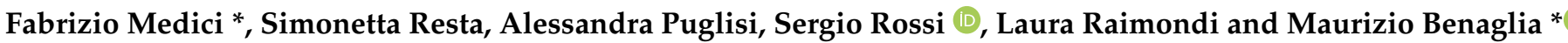

check for updates

Citation: Medici, F.; Resta, S.; Puglisi, A.; Rossi, S.; Raimondi, L.; Benaglia, M. Electrochemical Organic Synthesis of Electron-Rich Biaryl Scaffolds: An Update. Molecules 2021, 26, 6968. https://doi.org/10.3390/ molecules 26226968

Academic Editor: Carlo Santoro

Received: 28 October 2021

Accepted: 17 November 2021

Published: 18 November 2021

Publisher's Note: MDPI stays neutral with regard to jurisdictional claims in published maps and institutional affiliations.

Copyright: (c) 2021 by the authors. Licensee MDPI, Basel, Switzerland. This article is an open access article distributed under the terms and conditions of the Creative Commons Attribution (CC BY) license (https:// creativecommons.org/licenses/by/ $4.0 /)$.
Dipartimento di Chimica, Università degli Studi di Milano, Via Golgi 19, 20133 Milano, Italy; simonetta.resta@unimi.it (S.R.); alessandra.puglsi@unimi.it (A.P.); sergio.rossi@unimi.it (S.R.); lauramaria.raimondi@unimi.it (L.R.)

* Correspondence: fabrizio.medici@unimi.it (F.M.); Maurizio.benaglia@unimi.it (M.B.); Tel.: +39-02-5031-4171 (M.B.)

Abstract: Biaryl scaffolds are widely spread in biologically important natural products, in numerous therapeutic agents, but they are also considered a privileged class of ligands and (organo)catalysts; therefore, the development of efficient alternative methodologies to prepare such compounds is always attracting much attention. The present review discusses the organic electrosynthesis of biaryls starting from phenols, anilines, naphthols, and naphthylamines. The most significant examples of the works reported in the last decade are presented and classified according to the single class of molecules: after the introduction, the first three sections relate to the reactions of phenols, naphthols, and anilines, respectively; the other two sections refer to cross-coupling and miscellaneous reactions.

Keywords: biaryls; electrorganic synthesis; aryls coupling; electrodes; radical chemistry

\section{Introduction}

Biaryl systems were demonstrated to be pluripotent scaffolds in different fields. They can be found in a wide range of natural products (Figure 1) [1,2]; they are widely used as ligands in catalysis [3,4], and some of them are important bioactive molecules [5,6] or employed in materials [7] and agrochemicals [8].
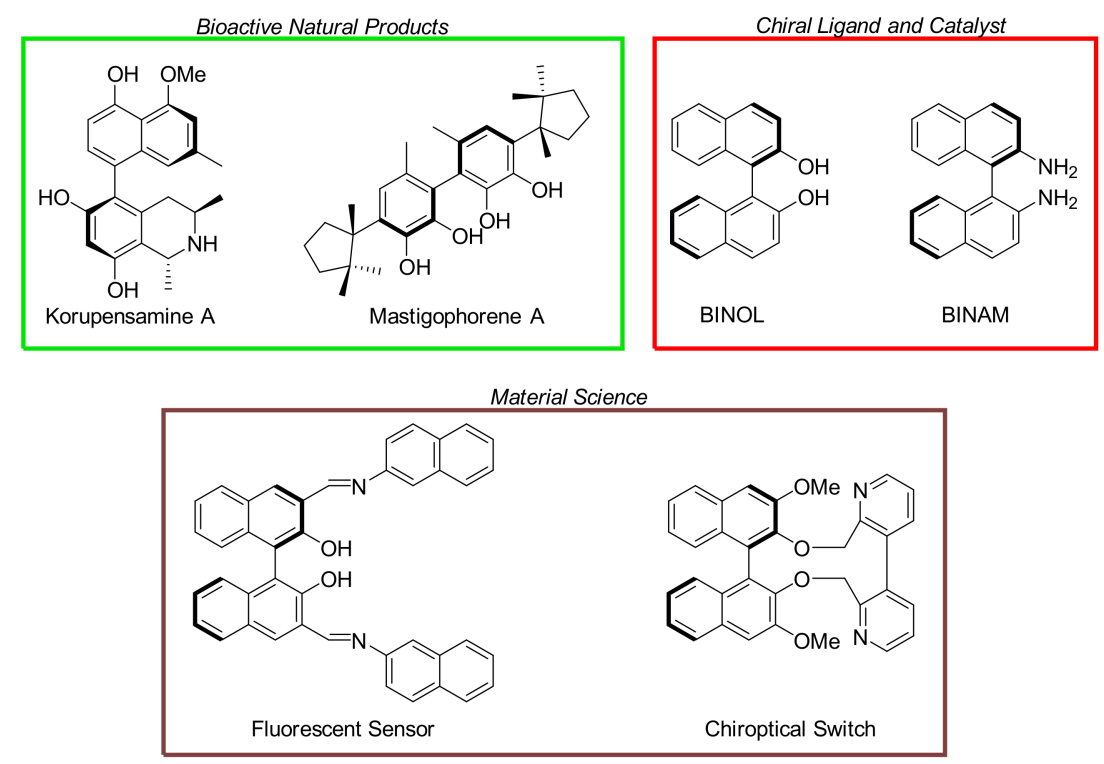

Figure 1. Example of biaryl scaffolds and their applications. 
Due to the prominent role of the biaryl scaffold, chemists in the last century have put a lot of effort into disclosing different synthetic pathways to assemble it. The possibilities are represented by the Ullmann reaction $[9,10]$, the Gomberg-Bachman arylation [11], transition metal catalysed cross-coupling [12,13], and by the more modern photo-splicing [14].

In the last 30 years, a "new" area of chemistry has started to play a more critical role in the synthesis: organic electrochemistry. As the name suggests, it uses electricity as a driving force to create new bonds and to build molecules in an easy and sometimes greener way compared to traditional methods, opening new and unconventional synthetic avenues out of the reach of the established chemistry [15-17]. The use of electrons as actual reagents in the chemical transformation set off the inessentiality of conventional oxidising and reducing agents. Additionally, they are renewable, inexpensive, and safe; fewer reagents implied less waste, meaning a greener reaction [18]. This review focuses on the contributions in the last decade in the area of electrocoupling reactions of phenols, anilines, naphthols, and naphthylamines to afford biaryl systems.

\section{Biphenols Electrosynthesis}

Biphenols represent a structural motif crucial in a wide range of natural products [19], ligands [20], and also materials chemistry [21]. The direct oxidation of phenol derivatives, with conventional method or by simple anodic treatment, results in forming a complex mixture of products (Scheme 1).

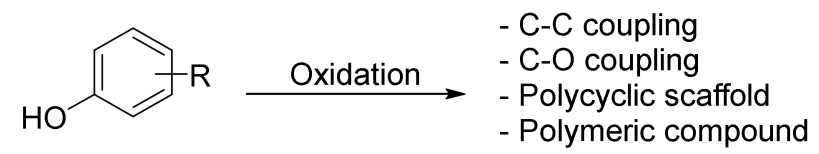

Scheme 1. Products mixtures from oxidation of phenols.

This problem was overcome with the introduction of the BDD (boron-doped diamond) electrode. It was then possible to generate the hydroxyl radical at a lower potential without generating $\mathrm{O}_{2}$ [22,23]. Further help also comes from fluorinated alcohols such as 1,1,1,3,3,3hexafluoroisopropanol (HFIP); fluorinated media in general, indeed, are able to lower the nucleophilicity of the substrates, such as phenols, due to the solvent shield effect generated through the high number of hydrogen bonding [24].

One of the first examples that demonstrated the potentiality of the BDD/HFIP couple was published by Kirste et al. (Scheme 2) in the anodic coupling of guaiacol [25].

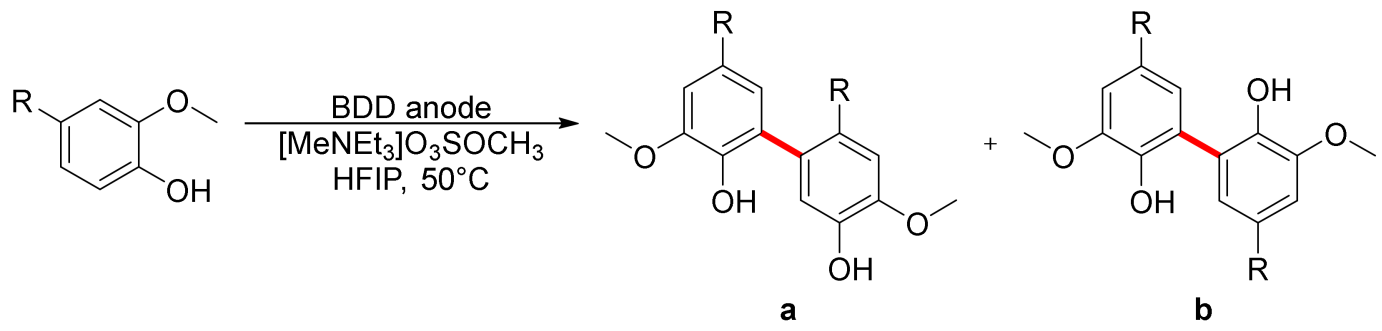

Scheme 2. Guaiacol derivatives electrocoupling products: non-symmetrical (a), symmetrical (b).

This reaction represented a significant breakthrough because it gave access to biaryl without the assistance of functional groups or the use of transition metals [26], resulting in a more atom-economy efficient and waste-free synthesis. The steric hindrance of the $\mathrm{R}$ group plays a fundamental role in dictating the final product of the reaction. If $\mathrm{R}$ is a bulky group, the formation of product $\mathbf{b}$ is favoured due to the less steric congestion in the final product. A mechanism was also proposed, and it is depicted in Scheme 3. 


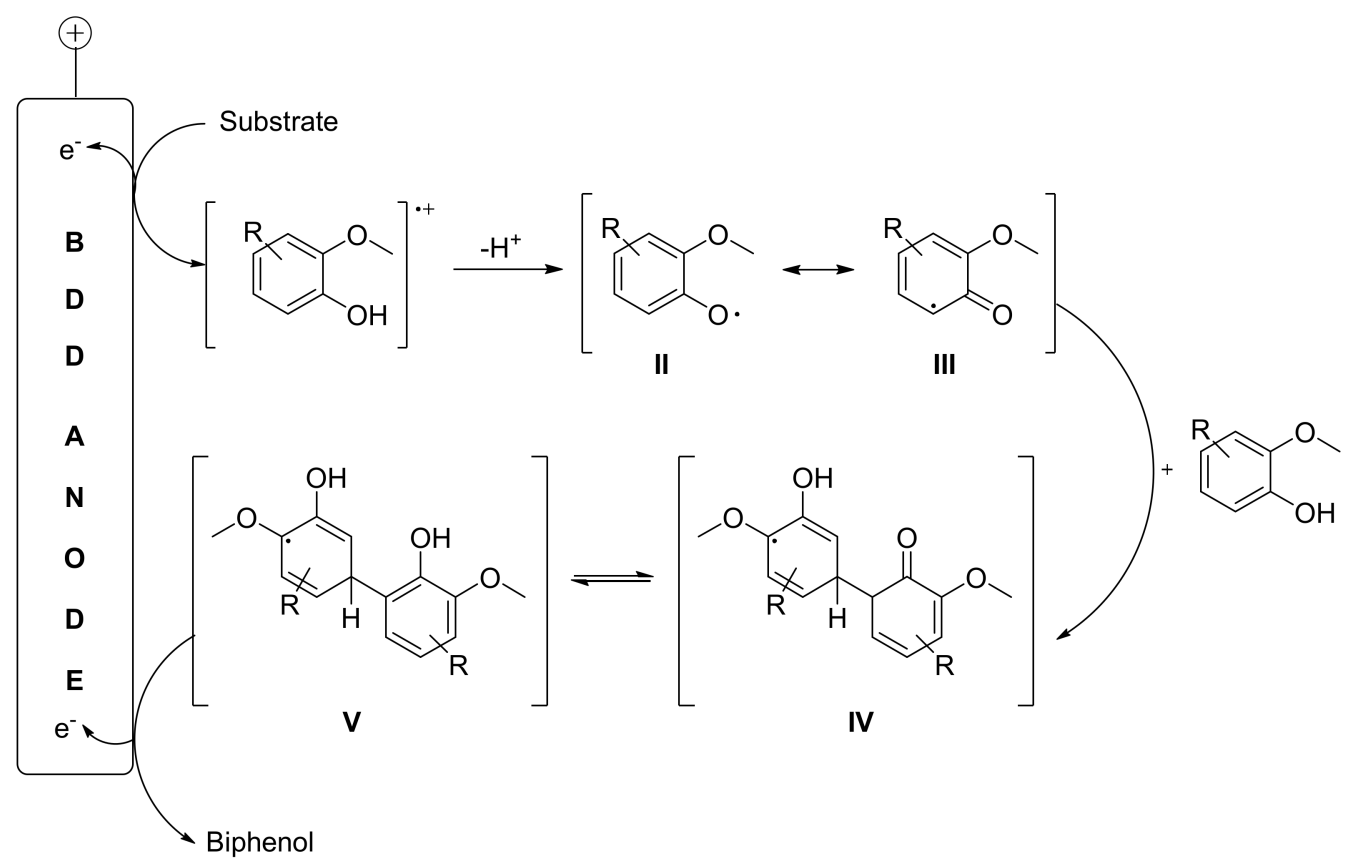

Scheme 3. Proposed mechanism for guaiacol anodic coupling.

The radical cation, derived from the oxidation of the substrate by the BDD anode, is characterised by an enhanced acidity; therefore, a spontaneous removal of a proton can occur, obtaining the phenoxyl radical, II/III. The intermediate is trapped by another molecule of starting material to generate IV in tautomeric equilibrium with $\mathbf{V}$ that undergoes single electron transfer to afford the desired biphenol. When a bulky group is present, the phenoxyl radical is attacked by the guaiacol in the less hindered position, causing the formation of the non-symmetrical compound.

Despite the good results obtained with the BDD/HFIP combination, Waldvogel's group searched for a cheaper and green alternative to fluorinated alcohol and the borondoped diamond [27]. Regarding the electrode, a suitable alternative was found to be graphite, known to be a trustworthy material for this kind of transformation $[28,29]$. However, when combined with HFIP, the reaction gave the desired product good yields $(50-60 \%)$, plus a significant amount of polymeric by-products. Another media was needed, and after an intense optimization study, TFA was found to be the best candidate (Scheme 4).

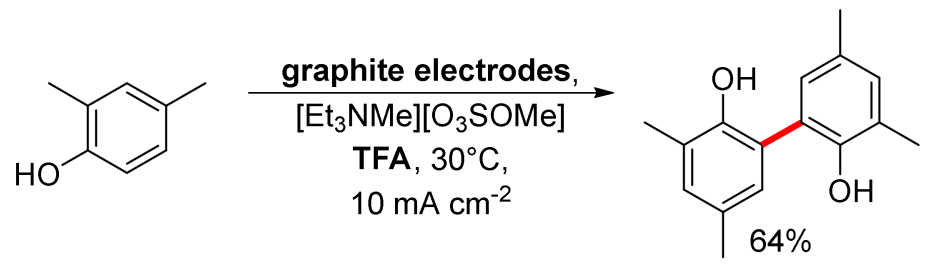

Scheme 4. Updated conditions for the electrochemical synthesis of phenols.

With the updated conditions, the reaction selectively gave the desired product in good yield; moreover, the starting material was easily recovered by short-path distillation. An improvement of this reaction is discussed in a recent paper of 2019 by Selt et al. [30]. 
In 2014, Elsler et al. broadened the reaction scope (Scheme 5) and accomplished the synthesis of non-symmetrical biphenol [31].

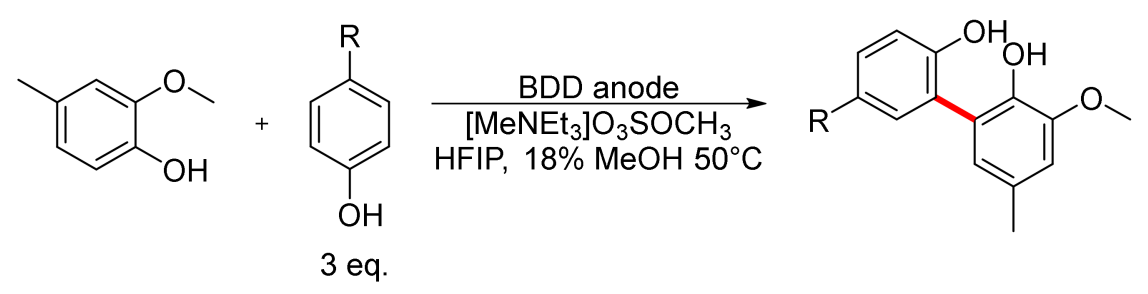

Scheme 5. Non-symmetrical electrocoupling of phenols.

To selectively obtain the non-symmetric product, the authors investigated the reaction conditions, and in particular, they used $\mathrm{MeOH}$ as an additive. In HFIP, methanol acts as a weak base interfering with the solvation and affecting the potential. Compared to other phenols, guaiacol has a minor oxidation potential, and with the addition of methanol, the potential difference is enhanced, lowering the guiacol one. Consequently, between the two reactions partners, the latter is be preferentially oxidised, and if phenol is present in large excess, the cross-coupling is the preferred final product. Besides, the low oxidation potential applied is not sufficient to oxidise the phenol, thus avoiding its homocoupling, even if present in excess. The reaction resulted suitable for a wide library of alkyl substituents as also some aryl moieties. As an additional value, in the paper, a greener synthetic route was developed; indeed, even if recyclable, fluorinated media still have a high environmental footprint. Preliminaries studies showed how formic acid could be a valuable alternative to HFIP [32]. Luckily, they were able to obtain the desired products, although in a lower yield, probably due to the inferior anodic stability of formic acid. Nevertheless, the low cost of the reactive compared to the fluorinated media make this result remarkable.

In 2016, Wiebe et al. carried out studies on electrocoupling using as substrates protected phenols, different from the methyl ether derivatives typically used in the previous examples [33], making the methodology appealing for different synthetic strategies, especially in the field of total synthesis.

Between the different protecting groups, only alkyl or silyl derivatives were suitable. In the end, silyl ethers, in particular TIPS, resulted in being the best choice for their simple cleavage procedure compared to alkyl derivatives [34].

The result showed in Scheme 6 highlights the robustness of the method. It is important to note that the TIPS also enhances the yields compared to the example with the unprotected phenols [31]. The authors explain these results as the combination of two different effects: the presence of a bulky group such as TIPS leads to a twist in the structure of the biphenol (Figure 2).<smiles>[R]c1ccc(O[SnH3])cc1</smiles>
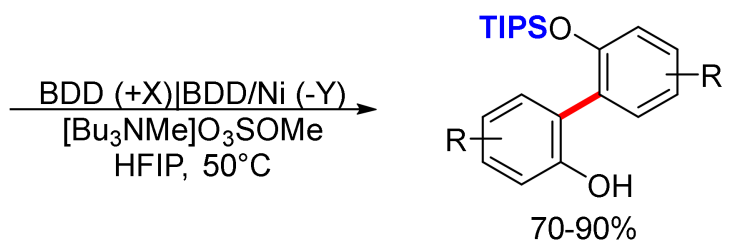

Scheme 6. Non-symmetrical partially protected phenol electrocoupling. 


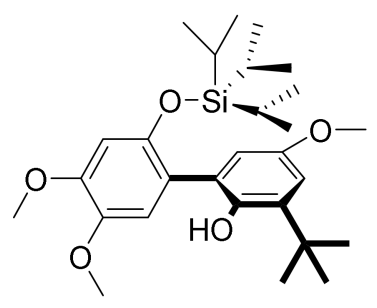

Figure 2. Molecular structure displaying the twist generated by TIPS.

This torsion is limited by an intramolecular hydrogen bonding between the $\mathrm{OH}$ and the silyl groups, to approximately $53^{\circ}$. In this conformation, the two $\pi$-systems are no longer conjugated. Therefore, the aryl moieties act as an EWG, protecting the final product from over oxidation. The second effect came from the solvation with HFIP. The two reaction partners are electron-rich systems that lead to strong solvation by the fluorinated media, which result in a decreased nucleophilicity penalising successive dehydrogenative couplings.

Thus far, all the reported examples have been focused on electron-rich phenols because more prone to oxidation. However, electron-poor biphenols are also attractive targets but more difficult to synthetize [31,35]. In 2020, however, Röchl et al. developed a method able to overcome this limitation [36]. One of the principal changes was the use of DIPEA instead of the supporting electrolyte (Scheme 7). The base, other than facilitating the conductivity of the solution, can also lower the oxidation potential of the starting materials. Unfortunately, it promotes the formation of the HFIP-ether [37,38]; in order to suppress this phenomenon, a low current density must be applied, a catalytic amount of DIPEA is used, and the concentration of a high substrate is required.<smiles>N#Cc1ccccc1O</smiles>

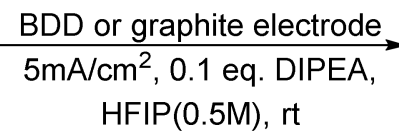<smiles>[R]c1ccc(-c2cc[R]c(C(C)(C)N)c2O)c(O)c1C#N</smiles>

Scheme 7. Optimised conditions for the coupling of electron-poor phenols.

With the exception of the aldehyde group, which easily gave over oxidation products, the method tolerates a wide variety of functional groups. Even if the yields are not excellent (30-64\% range), the starting material can be recovered and recycled. Of note, if pyridine is used instead of DIPEA, the preferential product would be the $\mathrm{C}-\mathrm{O}$ coupling. The mechanism proposed by the authors is presented in Scheme 8 .

After the SET from the substrate to the anode, the radical I can tautomerise to the solvated intermediate II or undergo another single electron transfer, which will lead to the HFIP-ether I $\mathbf{b}$. Thanks to the high starting material concentration, the Ib synthetic route is discarded. Nucleophilic attack from another molecule of phenol can lend to the $\mathrm{C}-\mathrm{C}$ or $\mathrm{C}-\mathrm{O}$ cross-coupling product. At this point, loss of an electron and consequent rearomatisation gave the desired compound. 


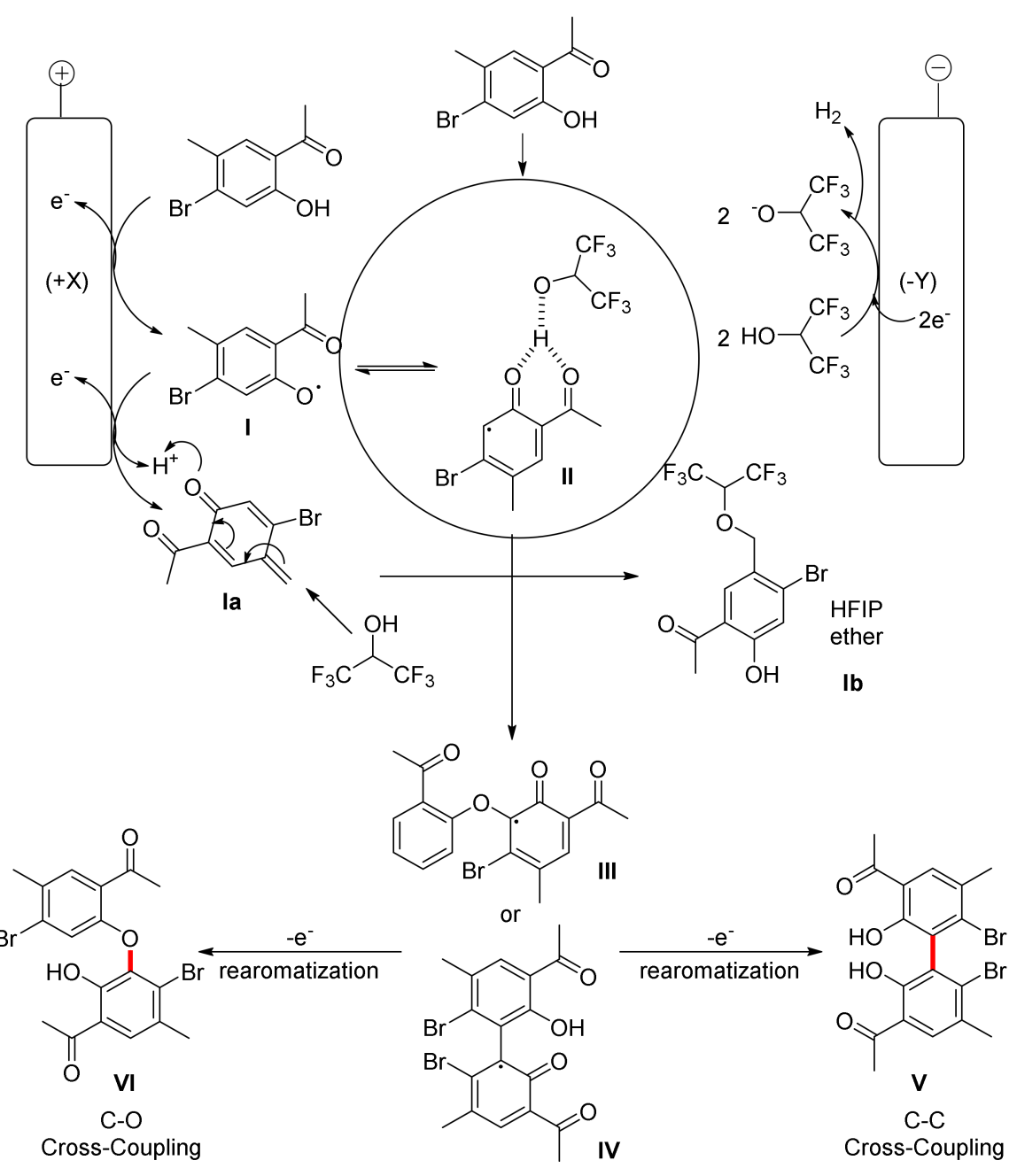

Scheme 8. Proposed mechanism by Röckl et al.

\section{Naphthols Electrocoupling}

BINOL and derivatives (Scheme 9) due to the possibility to be widely functionalised, and the intrinsic atropoisomerism had a big impact in the world of chiral ligands used in asymmetric catalysis, giving birth to different famous catalysts [39-41].

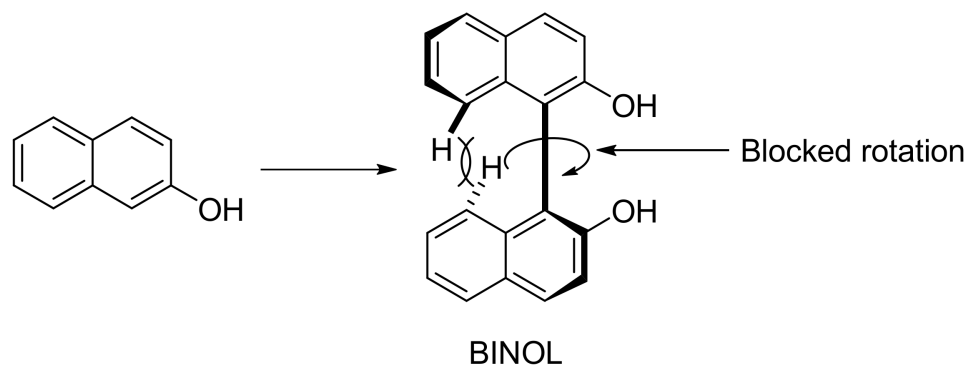

Scheme 9. BINOL atropoisomerism.

Nevertheless, for the synthesis of this very popular chiral scaffold, only organometallic or organocatalysed methods are known [41-45]. Electrochemistry represents a powerful and generally greener synthetic strategy; unfortunately, to the best of our knowledge, Waldvogel and co-workers, in a paper in 2011, presented in the previous section [23], reported only one example of 2-naphthol homo-electrocoupling (Scheme 10). Here, for the naphthol electrocoupling, TFA and HFIP were no more suitable media due to the 
insolubility of the substrates and the necessity to raise the temperature of the reaction. Heptafluorobutanoic acid resulted in being the best choice.

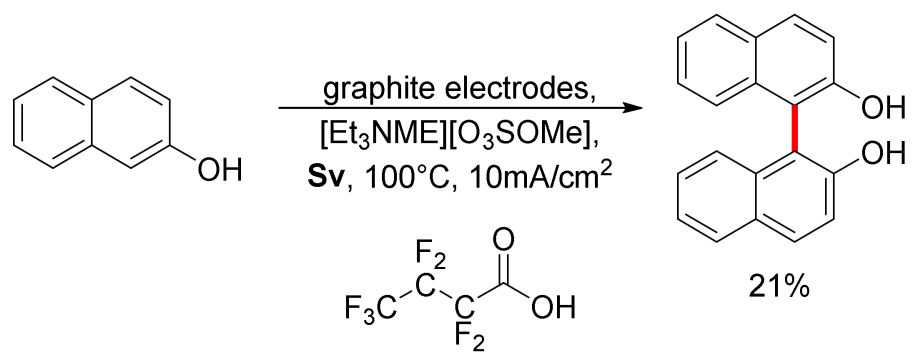

Sv: heptafluorobutanoic acid

Scheme 10. 2-naphthol homocoupling conditions.

The desired product was obtained in low yields; indeed, compared to phenols, naphthols are more labile to this kind of conditions, which generate different by-products.

\section{Aniline Electrocoupling}

Similar to phenols, anilines are one of the most crucial building blocks in chemistry. They are found in natural products, materials, and many other fields $[46,47]$. It was only a matter of time before electrochemistry started to investigate this class of compounds. Biaryl derived from aminobenzenes find applications in different fields as auxiliary ligands [48] or contrast agents [49]. However, their synthesis remains quite challenging for modern chemists. One of the principal reasons is the tendency to form different by-products, including "aniline black" [50] derived from the oxidative polymerisation of the aniline. The principal synthetic methods use organometallic catalysis [51,52].

In 2017, Waldwogel and co-workers were able to synthetize 2,2'-diamino biaryls with a metal-free protocol (Figure 3) [53]. However, some precautions are needed compared to the reaction with phenols; indeed, the low oxidation potential typical for this substrate promotes overoxidation, with consequent polymerisation [54]. In a recent publication, $\mathrm{N}$-metahanesulfonyl protected anilines were successfully employed in the coupling with different arenes. Of note, the use of other protecting groups, such as acetate or trifluoroacetate, Boc, and triflic groups, did not afford any of the desired coupling products [55].

1)<smiles>Nc1cc[R1]cc1</smiles>

A<smiles>Nc1ccccc1</smiles>

B<smiles>CC=CC</smiles><smiles>[R][R]1ccc(N)c(C2=CB=[R][R]C=C2N)c1</smiles><smiles>[14CH2][111Sn]</smiles>

+ oligomeric by-product

2)<smiles>CC(C)NC(=O)C(F)(F)C(=O)NC(C)C(C)(C)NC(=O)c1ccccc1</smiles>

Figure 3. (1) Direct oxidation of aniline. (2) Amine protecting group used by Waldvogel and co-workers.

CV studies of the $N$-protected anilines show an increase in the oxidation potential; for example, 3,4-dimethoxyaniline has an oxidation potential of $832 \mathrm{mV}$ in pure HFIP, while the potential of its $\mathrm{N}$-acetyl derivative is raised to $1.39 \mathrm{~V}$ (vs. $\mathrm{Ag} / \mathrm{AgCl}$ in saturated $\mathrm{LiCl} / \mathrm{EtOH})$, making the system less prone to over oxidation. Another tuneable parameter is the solvation. Anilines are both good acceptors and donors of H-bonds. Considering the impressive solvation of HFIP, a strong interaction is formed between the solvent and the reactant, with a dramatic lowering of the oxidation potential. For this reason, the addition 
of $\mathrm{MeOH}$ is required to disrupt the strong $\mathrm{H}$-bond interaction and modulate the potential. In this reaction, a considerable role is also played by the supporting electrolyte (Scheme 11).

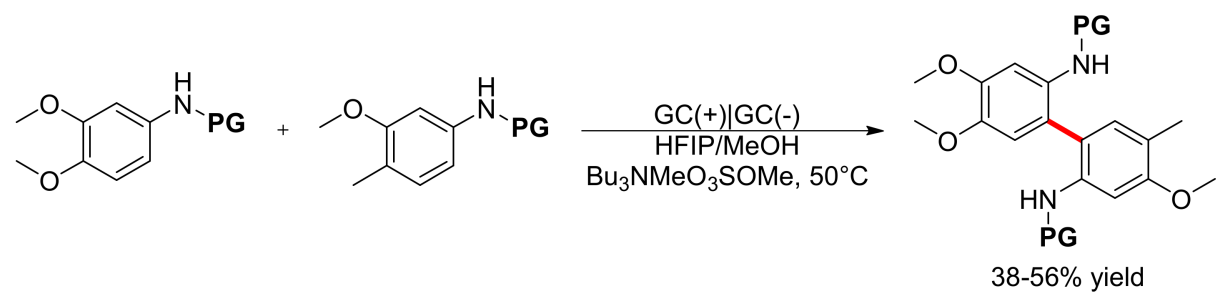

Scheme 11. Anodic oxidation of N-protected anilines.

The reaction gave moderate yields, but it is possible to recover the starting material during the purification. Moreover, no deprotection during the reaction was found to occur, regardless of the protective group that was used.

It is undoubtedly that a protecting group is necessary, so the Waldvogel group makes an intensive study on $N$-formyl derivatives (Scheme 12) [56], considering their synthetic interest $[57,58]$ and being the formyl group an atom-economic protecting group [59].

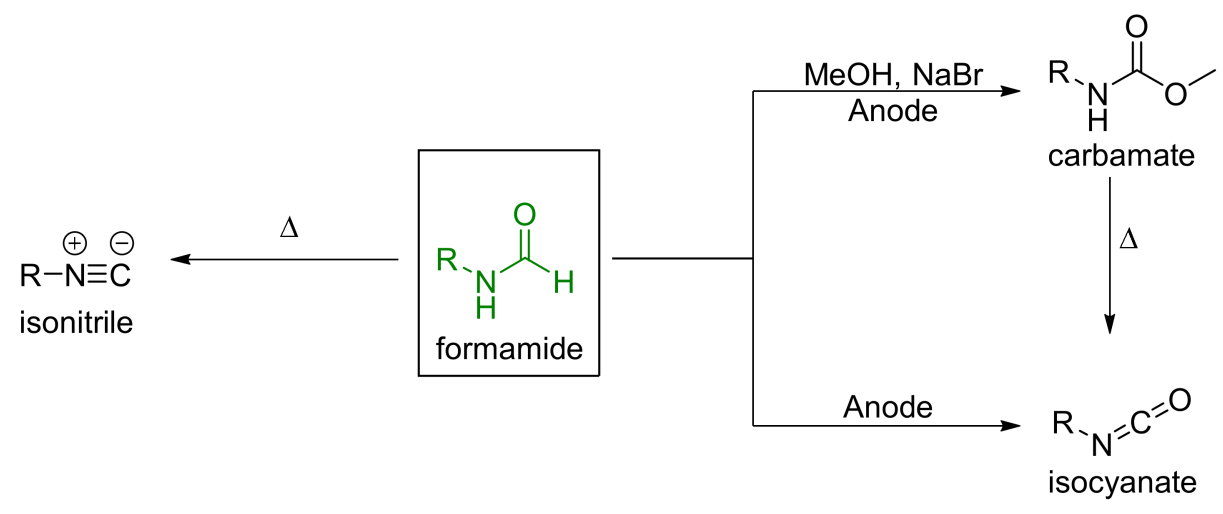

Scheme 12. Synthetic importance of formamides.

The methodology worked well also for this specific protecting group without observing degradation or deprotection. In addition, halogen-containing formanilides were used, and no side reactions or dehalogenation were observed.

Thus far, the reported coupling reactions were selective for the ortho-ortho C-C coupling. Thanks to the work of Gui and co-workers, it is now possible to have access to benzidine by electrochemical methods (Scheme 13) [60]. Moreover, these compounds, also known as 4,4'-diaminobiaryl, are found in various pharmaceutical products $[61,62]$ and as building blocks for the synthesis of heterocycles [1,63].
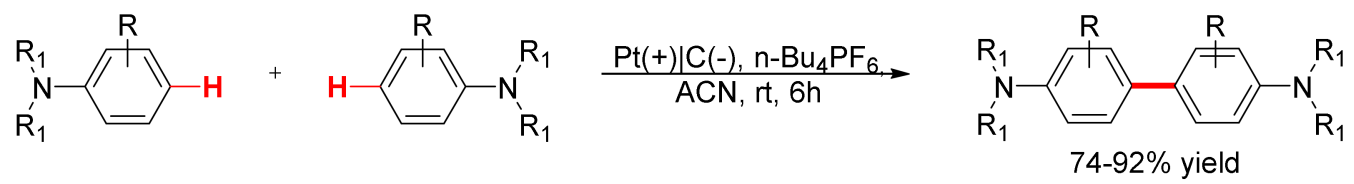

Scheme 13. Benzidine anodic coupling.

Aliphatic and aromatic $N$-protected anilines were also used with EWG and EDG groups as halogens. In addition, bulky protecting groups did not influence the overall yield. The authors stated that no ortho or meta coupling products were observed due to the high stability of the para-radical cation intermediate (Figure 4). 
<smiles></smiles>

Figure 4. Para-radical cation intermediate.

\section{Unsymmetrical Biaryl Electrosynthesis}

In the previous sections, homocoupling of different classes of compounds was discussed; however, unsymmetrical biaryls are also important and useful compounds (Figure 5). In the early 1990s, Hayashi [64], with MOP and Kocovsky [65] with NOBIN, gave birth to a new family of biaryl compounds that are applied in catalysis $[66,67]$ and also in medicinal chemistry $[68,69]$.<smiles>COc1ccc2ccccc2c1-c1c(P)ccc2ccccc12</smiles>

MOP<smiles>Nc1ccc2ccccc2c1-c1c(O)ccc2ccccc12</smiles>

NOBIN

Figure 5. Chemical structure of MOP and NOBIN.

Anodic treatment of arenes normally led to the starting material's homocoupling, and only a few examples gave the desired cross-coupling product [70]. Once again, the situation changed when the BDD electrode and fluorinated solvent were introduced (Scheme 14). In 2010, Waldvogel and co-workers devised a procedure with high selectivity toward cross-coupling [71].<smiles>[R]c1cc([R2])c(O)c([1H])c1</smiles>

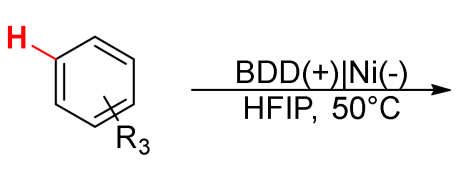<smiles>[R3]c1ccc(-c2cc([R])cc([R2])c2O)cc1</smiles>

Scheme 14. Phenol-Arene Anodic Cross-Coupling.

Compared to previous works, the best results and selectivity were obtained with the conditions shown in Scheme 14, with a lower current density, only $2.8 \mathrm{~mA} \mathrm{~cm}^{-2}$. The authors highlight the importance of the BDD electrode; indeed, when carbon-based electrodes were tested, only homo-dehydro dimers were found. A few years later, Waldvogel and co-workers improved their methodology with the introduction of additives as $\mathrm{MeOH}$ and $\mathrm{H}_{2} \mathrm{O}$ [72], whose effects were explained in the previous section.

With the idea to create a greener and cheaper protocol, Atobe and co-workers [73] looked for alternatives to the use of HFIP due to its high cost and non-negligible environmental footprint [74]. In order to mimic the effect of the perfluorinated alcohol, a solvent with a high acceptor number [75] is needed in order to stabilise the radical cation intermediate. Solvents with a high acceptor number (A.N.) are less prone to make a nucleophilic attack on the intermediate dystonic ion, extending its lifetime [76]. Methanol as an additive increased the selectivity between homo/cross-coupling (Table 1). 
Table 1. Acceptor Number of some of the solvents considered in Atobe's work.

\begin{tabular}{cc}
\hline Solvent & Acceptor Number \\
\hline HFIP & 88 \\
AcOH & 52.9 \\
HCOOH & 83.6 \\
TFA & 105 \\
\hline
\end{tabular}

In order to complete the portfolio of unsymmetrical electrocoupling reactions, several research groups introduced a different coupling partner other than arenes (Scheme 15). Once again, Waldvogel and co-workers, pioneer group in electrochemistry, opted to use 2-naphtylamine [77]. This class of compounds is relatively unexplored in the field of electrocoupling. For the homocoupling, only a paper from 1979 is known [78].
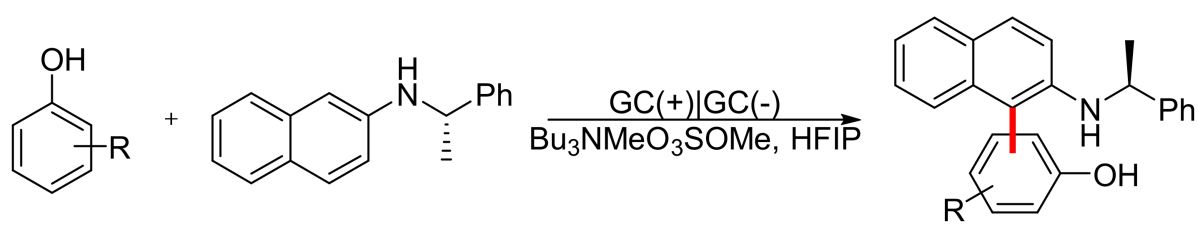<smiles>COc1cc(-c2c(N[C@H](C)c3ccccc3)ccc3ccccc23)c(O)c(C(C)(C)C)c1</smiles>

$48 \%$ yield<smiles>COc1ccc(Oc2c(N[C@H](C)c3ccccc3)ccc3ccccc23)cc1C</smiles>

$12 \%$ yield

Scheme 15. 2-Naphthylamine-phenol cross-coupling.

Besides the desired product, obtained in moderate yields, it was also noticed, in some cases, the formation of the $\mathrm{C}-\mathrm{O}$ cross-coupling product. In-deep investigations pointed out that the steric hindrance present on the ortho position of phenol is responsible for the final product structure. High steric hindrance leads to the $\mathrm{C}-\mathrm{C}$ coupling product, and low steric hindrance favours the $\mathrm{C}-\mathrm{O}$ connected compound. A drop in the yields was observed, probably due to the formation of a benzylic radical that is prone to side reactions, for phenols bearing methyl or ethyl moieties in para position.

To complete their investigation, they also decided to analyse the cross-coupling between naphthylamines and naphthol (Scheme 16).

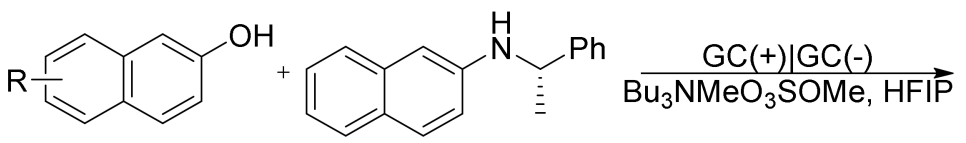<smiles></smiles>

$12-45 \%$ yields

Scheme 16. 2-naphtalymine 2-naphthol cross-coupling.

The setup was slightly different due to the minor electrochemical robustness of naphthol compared to phenol, being more prone to over-oxidation and side reaction. It was necessary to lower the current density and the temperature. On the other hand, an excess of alcohol was not necessary to ensure the cross-coupling, and, in all the cases, no $\mathrm{C}-\mathrm{O}$ coupling was observed. 
With the idea to demonstrate the potentiality of this reaction and to broaden the scope, Waldvogel's group investigated the functionalisation of benzofurans [79]. Their interest in this particular class of substances was born from the ubiquity of benzofurans in natural products and bioactive molecules [80-82].

Although the cross-coupling succeeded, the authors were quite surprised by the furan metathesis usually observed in all the reactions (Scheme 17). The data collected from the isolation of some intermediates suggest two different mechanisms, one starting from the 2-substituted benzofuran and one for 3-substituted one. The mechanism for the cross-coupling between phenol and 2-substituted benzofuran is reported in Scheme 18.

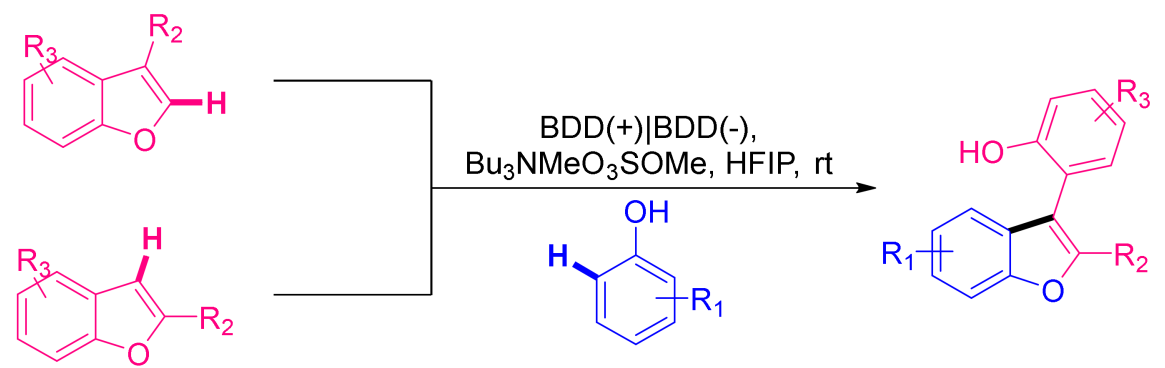

Scheme 17. Benzofuran phenol cross-coupling.
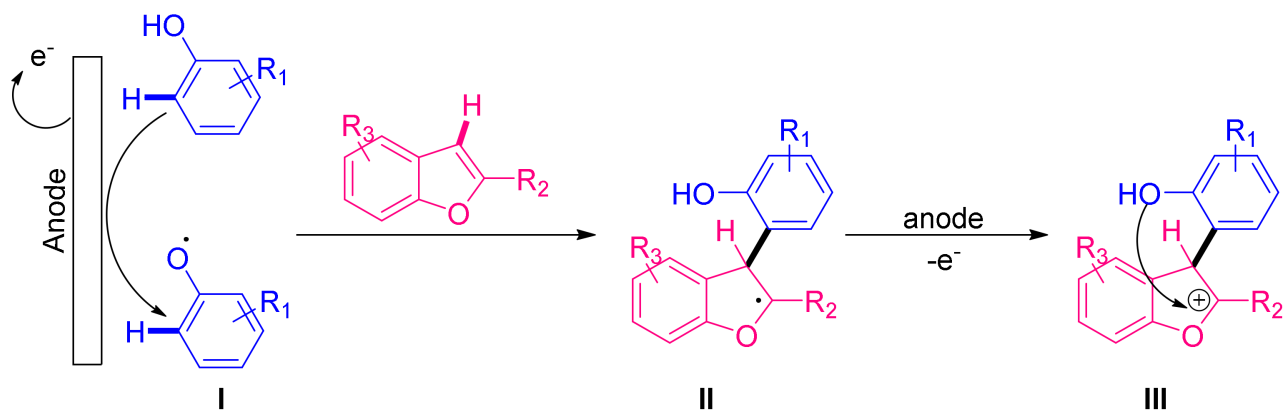

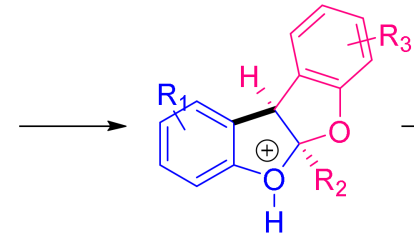

IV

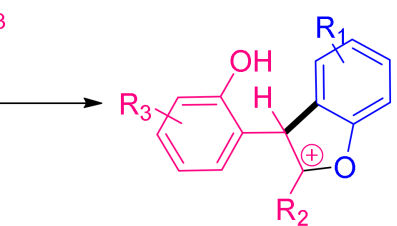

V

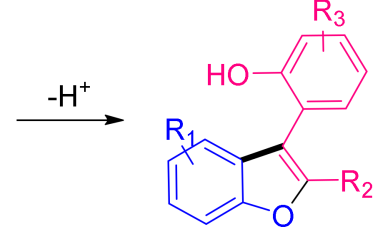

VI

Scheme 18. Proposed mechanism for the cross-coupling between phenol and 2-substituted benzofuran.

SET between the phenol, lowest oxidation potential, and the anode generate the phenoxyl radical that undergoes nucleophilic attack by the benzofuran. The neutral radical II is subject to another SET generating the carbocation in position 2 of the benzofuran moiety. Nucleophilic attack from the hydroxyl group affords the protonated dihydrobenzofuro $[2,3-b]$ benzofuran(IV). Rearrangement to the most stable carbocation (V) by ring-opening and consequent deprotonation led to the final product.

Regarding the 3-substituted benzofuran, the first steps are the same (Scheme 19); as the cationic intermediate $\mathbf{C}$ is formed, it undergoes an intramolecular attack at position 3 of the furan ring. The key intermediate $\mathbf{D}$ is the dihydrobenzofuro [3,2- $b]$ benzofuran and, as with IV ring-opening, evolves to the most stable carbocation. However, at this point, a 1,2-phenyl shift occurred due to the steric hindrance in position 2. Deprotonation of $\mathbf{F}$ and consequent rearomatisation give the desired compound. Waldvogel and co-workers noticed how the driving force of the mechanism is the greater stability of the carbocation V/E compared to IV/D. 


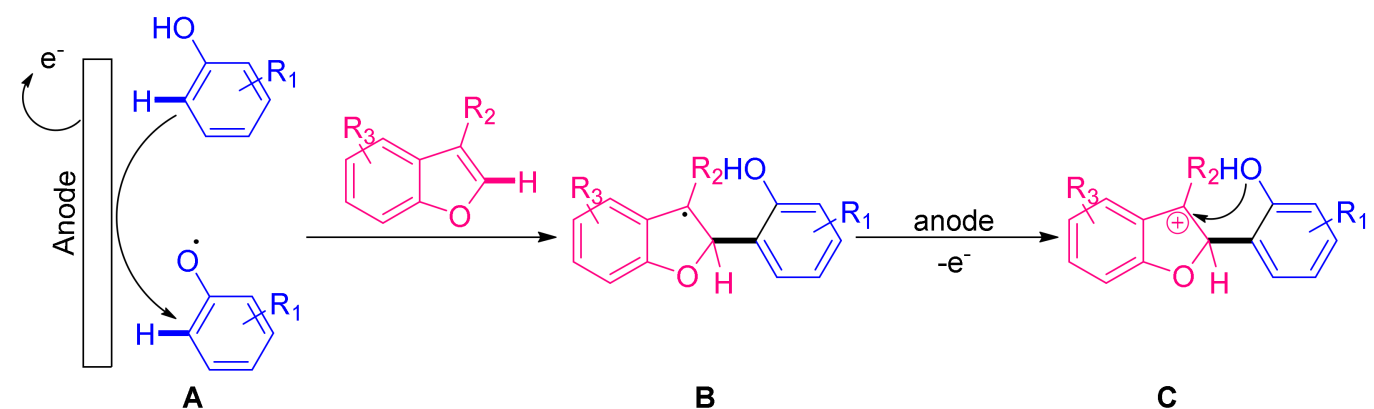

A<smiles>[R][R3]1cccc([C@H]2c3ccc([R])cc3OC2[R2])c1O</smiles><smiles>[R]c1cccc(-c2c([R])oc3ccccc23)c1O</smiles>

G

E

$$
[
$$

Rearrangement step:

Scheme 19. Proposed mechanism for the cross-coupling between phenol and 3-substituted benzofuran.

It is worth mentioning the work published by the group of Sun in 2019 [83]. They investigated the cross-coupling between phenols and 2-naphthol in the presence of a redox mediator: tetrabromophtalic anhydride, TBPA (Figure 6). Thanks to CV studies, they disclosed the ability of TBPA to act as an intermediary.<smiles>O=C1OC(=O)c2c(Br)c(Br)c(Br)c(Br)c21</smiles>

Tetrabromophtalyc anhydride TBPA

$$
\begin{aligned}
& \text { Anodic peak: } \\
& 0.84 \mathrm{~V}
\end{aligned}
$$<smiles>COc1cccc(OC)c1O</smiles>

2,4-dimethoxyphenol Anodic peak: $0.9 \mathrm{~V}$<smiles>Oc1ccc2ccccc2c1</smiles>

\section{2-naphthol}

Anodic peak: $1.05 \mathrm{~V}$

Figure 6. Oxidation potential of TBPA, 2,6-dimethylphenol, 2-naphthol. CV conditions: $0.1 \mathrm{~mol} / \mathrm{L}$ $\mathrm{LiClO}_{4} / \mathrm{CH}_{3} \mathrm{CN}$; Pt disk w. e.; $\mathrm{Ag}$ wire c. e.; $\mathrm{Ag} / \mathrm{AgNO}_{3} 0.1 \mathrm{~mol} / \mathrm{L}$ in $\mathrm{CH}_{3} \mathrm{CN}$ ref. e.

Indeed it has the lowest oxidation potential compared to 2,6-dimethoxyphenol and 2-naphthol. The slight potential difference between TBPA and the phenol suggests that the mediator's radical cation form will have a SET preferentially with the phenol generating the corresponding radical. The mediator strategy gave excellent results with an increased yield, up to $83 \%$, and a drastic enhancement of the selectivity towards the cross-coupling product. Furthermore, this methodology allowed the bis-arylation, in positions 1 and 4, when naphthol-2,3-diol is used.

Other than aromatic alcohols, also the nitrogen-containing counterpart was intensively studied. In 2020, the group of He developed a protocol for the cross-coupling between aniline and 2-naphthylamine [84]. The method is compatible with a wide variety of 
functional groups. It was possible to obtain also the product of cross/homo-coupling between naphthylamines (Figure 7), which was only partially achieved electrochemically in two papers of $1980[78,85]$.<smiles>CN(C)c1ccc2ccccc2c1-c1ccc(N(C)C)c2ccccc12</smiles>

$86 \%$ yield<smiles>Cc1ccc(-c2ccc(N(C)C)c3ccccc23)c2ccccc12</smiles>

$61 \%$ yield<smiles>CNc1ccc2ccccc2c1-c1c(NC)ccc2ccccc12</smiles>

$55 \%$ yield

Figure 7. Naphthylamines cross/homo-coupling.

\section{Miscellaneous}

In this final section, we focus our attention on a few interesting papers. In 2019, the group Chen published their studies on electrochemical regioselective $\mathrm{C}\left(\mathrm{sp}^{2}\right)-\mathrm{H}$ azolation of phenols [86]. Indeed, $\mathrm{N}$-arylated heterocycles are well-known in organic chemistry for their presence in natural products [87,88] and as functional material [89]. Although it is easy to oxidise both phenols and azoles electrochemically, their electro-combination was not achieved at the time $[90,91]$. Instead, this new reaction allows synthesising the desired product in high yields and with excellent regioselectivities.

The electrochemical conditions deserve a special comment. As depicted in Scheme 20, the reaction was conducted in potentiostat conditions instead of galvanostatic. Electrolysis with constant potential lends to the maximum selectivity because the potential of the reaction is set equal to that of the starting material but is generally slower and with a more complicated setup (working electrode, counter electrode, reference electrode) [73]. The reaction also worked with anilines, and excellent yields were obtained with a high tolerance of different functional groups. Further control experiments were carried out to gain some insights into the mechanism. From them, they established that: (a) Phenol does not form the corresponding dystonic cation. Instead, it is the pyrazole to undergo oxidation; (b) In the case of aniline, experiments suggest the formation of N-centered radical; (c) Michael's addition pathway must be excluded.<smiles>COc1ccc(O)cc1</smiles>

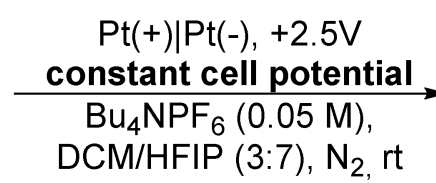

constant cell potentia $\mathrm{Bu}_{4} \mathrm{NPF}_{6}(0.05 \mathrm{M})$
$\mathrm{DCM} / \mathrm{HFIP}(3: 7), \mathrm{N}_{2}$<smiles>COc1ccc(O)c(-n2cccn2)c1</smiles>

$97 \%$ yield

Scheme 20. Electrochemical N-arylation of Azole.

The other mention is dedicated to a recent paper from the group of Vercammen [92]. Unlike the other examples reported in the previous sections, in which the $\mathrm{C}-\mathrm{C}$ coupling was the objective, the authors developed a methodology for the $\mathrm{C}-\mathrm{O}$ coupling between phenol and aniline to afford diaryl ethers, important compounds as bioactive molecules [93-95]. In order to enhance the yield of the desired product and based on the results obtained by Waldvogel in some isolated cases [36,77], they opted for the following substrates: phenols with low steric hindrance, aniline with para position activated, and with a low oxidation potential (Scheme 21). 


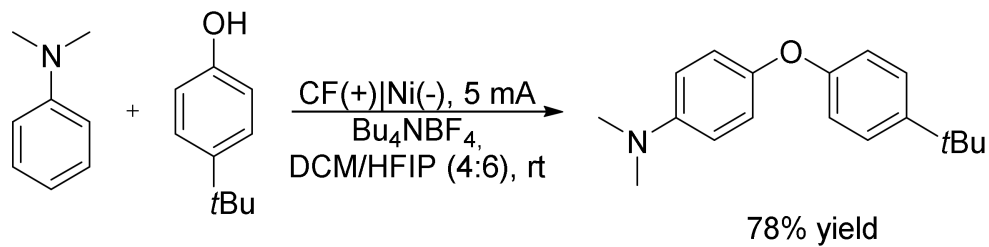

Scheme 21. Diaryl ether electrosynthesis.

When only DCM or HFIP were used, a drastic yield drop is observed, as with MeOH and CAN; the reaction also resulted quite sensible to the cathode material. Indeed, when a Pd electrode was used, a decrease in yield was observed. This behaviour can be ascribed to a reduction step, fundamental for the mechanism, highly dependent on the surface properties of the electrode. Homocoupling, one of the principal parasite reactions in electrochemical reactions, was observed in rare cases and only in traces. CV and EPR analysis of the reaction crude confirmed that the first species to be oxidised is the aniline. The following mechanism was then proposed (Figure 8).

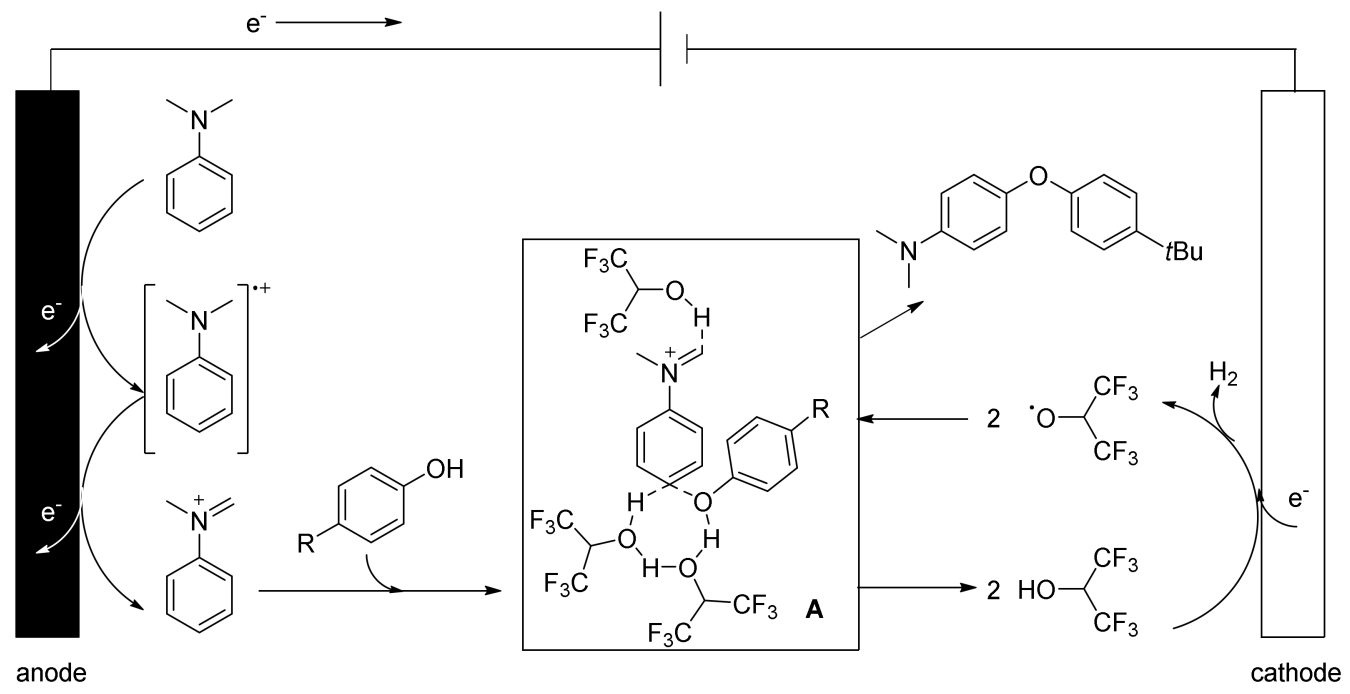

Figure 8. Proposed mechanism for $\mathrm{C}\left(\mathrm{sp}^{2}\right)-\mathrm{O}$ coupling.

Anodic oxidation of the tertiary aniline generates the corresponding cation that is attacked by the phenol. Besides decreasing the nucleophilicity and the possibility of sidereactions, HFIP acts as a mediator between the cathode and the solvated intermediate $\mathbf{A}$, facilitating the hydrogen transfer necessary to obtain the final product. High tolerance to a wide variety of functional groups was observed.

\section{Conclusions}

In the last decade, electrochemistry has become a valuable method for the synthesis of biaryl, thanks to the introduction of BDD as a new electrode combined with the versatility of the fluorinated media, especially HFIP. The efforts of different groups resulted in the development of a variety of new reactions applicable to a vast library of biaryl substrates. In addition, the reagent role is taken by electrons instead of oxidising or reducing agents, which makes the reaction greener thanks to the decreased production of waste.

In the case of aryl coupling, efficient methodologies for the enantioselective synthesis of not-racemic biaryl are clearly underdeveloped. In 1994, the electrocatalytic oxidative coupling of naphthol on a TEMPO-modified felt electrode in the presence of sparteine was described [96]. However, since then, no further examples have been reported, and new contributions in the area are expected and are largely desirable. 
As regards the future, we also foresee a major entanglement between flow chemistry and electrochemistry. The new asset will further increase the attractiveness of electrosynthesis [97-99]. The chemistry is also evolving toward a greener approach; therefore, new eco-friendly protocols could be envisioned, such as the one where Deep Eutectic Solvents were used as green media [100,101].

Author Contributions: Conceptualization and writing —original draft preparation, F.M. and M.B.; writing - review and editing S.R. (Simonetta Resta), A.P., L.R. and S.R. (Sergio Rossi). All authors have read and agreed to the published version of the manuscript.

Funding: This research was funded by European Community-MSCA-ITN-EID project Technotrain: TECHNOTRAIN-H2020-MSCA-ITN-2018 Grant Agreement 812944.

Institutional Review Board Statement: Not applicable.

Informed Consent Statement: Not applicable.

Data Availability Statement: Not applicable.

Conflicts of Interest: The authors declare no conflict of interes.

\section{References}

1. Yuan, S.; Chang, J.; Yu, B. Construction of Biologically Important Biaryl Scaffolds through Direct C-H Bond Activation: Advances and Prospects. Top. Curr. Chem. Z 2020, 378, 23. [CrossRef]

2. Ali, S.; Asad, M.H.H.B.; Khan, F.; Murtaza, G.; Rizvanov, A.A.; Iqbal, J.; Babak, B.; Hussain, I. Biological Evaluation of Newly Synthesized Biaryl Guanidine Derivatives to Arrest $\beta$-Secretase Enzymatic Activity Involved in Alzheimer's Disease. BioMed Res. Int. 2020, 2020, e8934289. [CrossRef] [PubMed]

3. Biosca, M.; Pàmies, O.; Diéguez, M. Ir-Biaryl Phosphite-Oxazoline Catalyst Libraries: A Breakthrough in the Asymmetric Hydrogenation of Challenging Olefins. Catal. Sci. Technol. 2020, 10, 613-624. [CrossRef]

4. Fuentes-Rivera, J.J.; Zick, M.E.; Düfert, M.A.; Milner, P.J. Overcoming Halide Inhibition of Suzuki-Miyaura Couplings with Biaryl Monophosphine-Based Catalysts. Org. Process Res. Dev. 2019, 23, 1631-1637. [CrossRef]

5. Yoganathan, S.; Alagaratnam, A.; Acharekar, N.; Kong, J. Ellagic Acid and Schisandrins: Natural Biaryl Polyphenols with Therapeutic Potential to Overcome Multidrug Resistance in Cancer. Cells 2021, 10, 458. [CrossRef] [PubMed]

6. Flick, A.C.; Ding, H.X.; Leverett, C.A.; Kyne, R.E.; Liu, K.K.-C.; Fink, S.J.; O’Donnell, C.J. Synthetic Approaches to the New Drugs Approved During 2015. J. Med. Chem. 2017, 60, 6480-6515. [CrossRef]

7. Zhu, S.S.; Swager, T.M. Design of Conducting Redox Polymers: A Polythiophene-Ru(Bipy)3;N $\oplus$ Hybrid Material. Adv. Mater. 1996, 8, 497-500. [CrossRef]

8. Baudoin, O.; Cesario, M.; Guénard, D.; Guéritte, F. Application of the Palladium-Catalysed Borylation/Suzuki Coupling (BSC) Reaction to the Synthesis of Biologically Active Biaryl Lactams. J. Org. Chem. 2002, 67, 1199-1207. [CrossRef] [PubMed]

9. Gong, X.; Wu, J.; Meng, Y.; Zhang, Y.; Ye, L.-W.; Zhu, C. Ligand-Free Palladium Catalyzed Ullmann Biaryl Synthesis: 'Household' Reagents and Mild Reaction Conditions. Green Chem. 2019, 21, 995-999. [CrossRef]

10. Ullmann, F.; Bielecki, J. Ueber Synthesen in der Biphenylreihe. Ber. Dtsch. Chem. Ges. 1901, 34, 2174-2185. [CrossRef]

11. Amaya, T.; Jin, Y.; Tobisu, M. Recent Advances in Gomberg-Backmann Biaryl Synthesis. Tetrahedron Lett. 2019, 60, 151062. [CrossRef]

12. Qiu, H.; Shuai, B.; Wang, Y.-Z.; Liu, D.; Chen, Y.-G.; Gao, P.-S.; Ma, H.-X.; Chen, S.; Mei, T.-S. Enantioselective Ni-Catalysed Electrochemical Synthesis of Biaryl Atropisomers. J. Am. Chem. Soc. 2020, 142, 9872-9878. [CrossRef] [PubMed]

13. Liao, G.; Zhou, T.; Yao, Q.-J.; Shi, B.-F. Recent Advances in the Synthesis of Axially Chiral Biaryls via Transition Metal-Catalysed Asymmetric C-H Functionalization. Chem. Commun. 2019, 55, 8514-8523. [CrossRef] [PubMed]

14. Kloss, F.; Neuwirth, T.; Haensch, V.G.; Hertweck, C. Metal-Free Synthesis of Pharmaceutically Important Biaryls by Photosplicing. Angew. Chem. Int. Ed. 2018, 57, 14476-14481. [CrossRef] [PubMed]

15. Pollok, D.; Waldvogel, S.R. Electro-Organic Synthesis-A 21st Century Technique. Chem. Sci. 2020, 11, 12386-12400. [CrossRef]

16. Pletcher, D. Organic Electrosynthesis-A Road to Greater Application. A Mini Review. Electrochem. Commun. 2018, 88, 1-4. [CrossRef]

17. Utley, J. Trends in Organic Electrosynthesis. Chem. Soc. Rev. 1997, 26, 157-167. [CrossRef]

18. Yuan, Y.; Lei, A. Is Electrosynthesis Always Green and Advantageous Compared to Traditional Methods? Nat. Commun. 2020, 11, 802. [CrossRef]

19. Bringmann, G.; Gulder, T.; Gulder, T.A.M.; Breuning, M. Atroposelective Total Synthesis of Axially Chiral Biaryl Natural Products. Chem. Rev. 2011, 111, 563-639. [CrossRef]

20. Hua, Z.; Vassar, V.C.; Choi, H.; Ojima, I. New Biphenol-Based, Fine-Tunable Monodentate Phosphoramidite Ligands for Catalytic Asymmetric Transformations. Proc. Natl. Acad. Sci. USA 2004, 101, 5411-5416. [CrossRef] 
21. Van Leeuwen, P.W.N.M.; Kamer, P.C.J.; Claver, C.; Pàmies, O.; Diéguez, M. Phosphite-Containing Ligands for Asymmetric Catalysis. Chem. Rev. 2011, 111, 2077-2118. [CrossRef]

22. Cobb, S.J.; Ayres, Z.J.; Macpherson, J.V. Boron Doped Diamond: A Designer Electrode Material for the Twenty-First Century. Annu. Rev. Anal. Chem. 2018, 11, 463-484. [CrossRef] [PubMed]

23. Macpherson, J.V. A Practical Guide to Using Boron Doped Diamond in Electrochemical Research. Phys. Chem. Chem. Phys. 2015, 17, 2935-2949. [CrossRef] [PubMed]

24. Colomer, I.; Chamberlain, A.E.R.; Haughey, M.B.; Donohoe, T.J. Hexafluoroisopropanol as a Highly Versatile Solvent. Nat. Rev. Chem. 2017, 1, 1-12. [CrossRef]

25. Kirste, A.; Schnakenburg, G.; Waldvogel, S.R. Anodic Coupling of Guaiacol Derivatives on Boron-Doped Diamond Electrodes. Org. Lett. 2011, 13, 3126-3129. [CrossRef]

26. Hussain, I.; Singh, T. Synthesis of Biaryls through Aromatic C- Bond Activation: A Review of Recent Developments. Adv. Synth. Catal. 2014, 356, 1661-1696. [CrossRef]

27. Kirste, A.; Hayashi, S.; Schnakenburg, G.; Malkowsky, I.M.; Stecker, F.; Fischer, A.; Fuchigami, T.; Waldvogel, S.R. Highly Selective Electrosynthesis of Biphenols on Graphite Electrodes in Fluorinated Media. Chem. Eur. J. 2011, 17, 14164-14169. [CrossRef] [PubMed]

28. Degner, D. Organic electrosyntheses in industry. In Proceedings of the Electrochemistry III; Stekchan, E., Ed.; Springer: Berlin/Heidelberg, Germany, 1988; pp. 1-95.

29. Baumgärtel, H.F. Beck: Elektroorganische Chemie, Verlag Chemie, Weinheim 1974, 391 Seiten, Preis: DM 88,- - Ber. Bunsenges. Phys. Chem. 1975, 79, 716. [CrossRef]

30. Selt, M.; Mentizi, S.; Schollmeyer, D.; Franke, R.; Waldvogel, S.R. Selective and Scalable Dehydrogenative Electrochemical Synthesis of 3,3',5,5'-Tetramethyl-2,2'-Biphenol. Synlett 2019, 30, 2062-2067. [CrossRef]

31. Elsler, B.; Schollmeyer, D.; Dyballa, K.M.; Franke, R.; Waldvogel, S.R. Metal- and Reagent-Free Highly Selective Anodic CrossCoupling Reaction of Phenols. Angew. Chem. Int. Ed. 2014, 53, 5210-5213. [CrossRef] [PubMed]

32. Atobe, M.; Tateno, H.; Matsumura, Y. Applications of Flow Microreactors in Electrosynthetic Processes. Chem. Rev. 2018, 118, 4541-4572. [CrossRef]

33. Wiebe, A.; Schollmeyer, D.; Dyballa, K.M.; Franke, R.; Waldvogel, S.R. Selective Synthesis of Partially Protected Nonsymmetric Biphenols by Reagent- and Metal-Free Anodic Cross-Coupling Reaction. Angew. Chem. Int. Ed. 2016, 55, 11801-11805. [CrossRef] [PubMed]

34. Ruecker, C. The Triisopropylsilyl Group in Organic Chemistry: Just a Protective Group, or More? Chem. Rev. 1995, 95, 1009-1064. [CrossRef]

35. Li, X.; Hewgley, J.B.; Mulrooney, C.A.; Yang, J.; Kozlowski, M.C. Enantioselective Oxidative Biaryl Coupling Reactions Catalysed by 1,5-Diazadecalin Metal Complexes: Efficient Formation of Chiral Functionalized BINOL Derivatives. J. Org. Chem. 2003, 68, 5500-5511. [CrossRef] [PubMed]

36. Röckl, J.L.; Schollmeyer, D.; Franke, R.; Waldvogel, S.R. Dehydrogenative Anodic C-C Coupling of Phenols Bearing ElectronWithdrawing Groups. Angew. Chem. Int. Ed. 2020, 59, 315-319. [CrossRef]

37. Röckl, J.L.; Imada, Y.; Chiba, K.; Franke, R.; Waldvogel, S.R. Dehydrogenative Anodic Cyanation Reaction of Phenols in Benzylic Positions. ChemElectroChem 2019, 6, 4184-4187. [CrossRef]

38. Imada, Y.; Röckl, J.L.; Wiebe, A.; Gieshoff, T.; Schollmeyer, D.; Chiba, K.; Franke, R.; Waldvogel, S.R. Metal- and Reagent-Free Dehydrogenative Formal Benzyl-Aryl Cross-Coupling by Anodic Activation in 1,1,1,3,3,3-Hexafluoropropan-2-Ol. Angew. Chem. Int. Ed. 2018, 57, 12136-12140. [CrossRef]

39. Terada, M.; Gupta, Y.; Kikuchi, J. Bis-Phosphoric Acid Derived from BINOL Dimer as a Chiral Brønsted Acid Catalyst for Enantioselective Transformations. Chem. Lett. 2019, 48, 260-263. [CrossRef]

40. Sasai, H.; Suzuki, T.; Arai, S.; Arai, T.; Shibasaki, M. Basic Character of Rare Earth Metal Alkoxides. Utilisation in Catalytic Carbon-Carbon Bond-Forming Reactions and Catalytic Asymmetric Nitroaldol Reactions. J. Am. Chem. Soc. 1992, 114, 4418-4420. [CrossRef]

41. Wu, Y.; Yang, L.; Wu, B.; Li, J.; Liu, B.; Ke, G.; Dong, F.; Zhou, Y.; He, H. Accurate Understanding the Catalytic Role of MnO2 in the Oxidative-Coupling of 2-Naphthols into 1,1'-Bi-2-Naphthols. Catal. Lett. 2021, 151, 901-908. [CrossRef]

42. Hayashi, H.; Ueno, T.; Kim, C.; Uchida, T. Ruthenium-Catalyzed Cross-Selective Asymmetric Oxidative Coupling of Arenols. Org. Lett. 2020, 22, 1469-1474. [CrossRef] [PubMed]

43. Shirakawa, S.; Maruoka, K. A New Strategy for Organocatalyzed Asymmetric Synthesis of BINOL Derivatives. Chem 2017, 2, 329-331. [CrossRef]

44. Takizawa, S.; Katayama, T.; Kameyama, C.; Onitsuka, K.; Suzuki, T.; Yanagida, T.; Kawai, T.; Sasai, H. Chiral Dinuclear Vanadium(V) Catalysts for Oxidative Coupling of 2-Naphthols. Chem. Commun. 2008, 15, 1810-1812. [CrossRef] [PubMed]

45. Luo, Z.; Liu, Q.; Gong, L.; Cui, X.; Mi, A.; Jiang, Y. Novel Achiral Biphenol-Derived Diastereomeric Oxovanadium(IV) Complexes for Highly Enantioselective Oxidative Coupling of 2-Naphthols. Angew. Chem. Int. Ed. 2002, 41, 4532-4535. [CrossRef]

46. Anjalin, M.; Kanagathara, N.; Baby Suganthi, A.R. A Brief Review on Aniline and Its Derivatives. Mater. Today Proc. 2020, 33, 4751-4755. [CrossRef]

47. Amini, B.; Lowenkron, S. Aniline and its derivatives. In Kirk-Othmer Encyclopedia of Chemical Technology; American Cancer Society: New York, NY, USA, 2003; ISBN 978-0-471-23896-6. 
48. Nakatsuka, H.; Yamamura, T.; Shuto, Y.; Tanaka, S.; Yoshimura, M.; Kitamura, M. Mechanism of Asymmetric Hydrogenation of Aromatic Ketones Catalysed by a Combined System of $\mathrm{Ru}(\pi-\mathrm{CH} 2 \mathrm{C}(\mathrm{CH} 3) \mathrm{CH} 2) 2(\mathrm{Cod})$ and the Chiral Sp2N/Sp3NH Hybrid Linear N4 Ligand Ph-BINAN-H-Py. J. Am. Chem. Soc. 2015, 137, 8138-8149. [CrossRef] [PubMed]

49. Jung, K.-H.; Kim, H.-K.; Lee, G.H.; Kang, D.-S.; Park, J.-A.; Kim, K.M.; Chang, Y.; Kim, T.-J. Gd Complexes of Macrocyclic Diethylenetriaminepentaacetic Acid (DTPA) Biphenyl-2,2'-Bisamides as Strong Blood-Pool Magnetic Resonance Imaging Contrast Agents. J. Med. Chem. 2011, 54, 5385-5394. [CrossRef] [PubMed]

50. Letheby, H. XXIX.-On the Production of a Blue Substance by the Electrolysis of Sulphate of Aniline. J. Chem. Soc. 1862, 15, 161-163. [CrossRef]

51. Long, C.-Y.; Ni, S.-F.; Su, M.-H.; Wang, X.-Q.; Tan, W. Highly Chemoselective Access to 2,2'-Diaminobiaryls via Ni-Catalyzed Protecting-Group-Free Coupling of 2-Haloanilines. ACS Catal. 2020, 10, 13641-13649. [CrossRef]

52. Hiroto, S. Synthesis of $\pi$-Functional Molecules through Oxidation of Aromatic Amines. Chem. Asian J. 2019, 14, $2514-2523$. [CrossRef]

53. Schulz, L.; Enders, M.; Elsler, B.; Schollmeyer, D.; Dyballa, K.M.; Franke, R.; Waldvogel, S.R. Reagent- and Metal-Free Anodic C-C Cross-Coupling of Aniline Derivatives. Angew. Chem. Int. Ed. 2017, 56, 4877-4881. [CrossRef] [PubMed]

54. Souto, J.A.; Martínez, C.; Velilla, I.; Muñiz, K. Defined Hypervalent Iodine(III) Reagents Incorporating Transferable Nitrogen Groups: Nucleophilic Amination through Electrophilic Activation. Angew. Chem. Int. Ed. 2013, 52, 1324-1328. [CrossRef] [PubMed]

55. Ito, M.; Kubo, H.; Itani, I.; Morimoto, K.; Dohi, T.; Kita, Y. Organocatalytic C-H/C-H' Cross-Biaryl Coupling: C-Selective Arylation of Sulfonanilides with Aromatic Hydrocarbons. J. Am. Chem. Soc. 2013, 135, 14078-14081. [CrossRef]

56. Schulz, L.; Franke, R.; Waldvogel, S.R. Direct Anodic Dehydrogenative Cross- and Homo-Coupling of Formanilides. ChemElectroChem 2018, 5, 2069-2072. [CrossRef]

57. Kohlmeyer, C.; Schäfer, A.; Huy, P.H.; Hilt, G. Formamide-Catalyzed Nucleophilic Substitutions: Mechanistic Insight and Rationalisation of Catalytic Activity. ACS Catal. 2020, 10, 11567-11577. [CrossRef]

58. Jin, Z.; Li, Y.-J.; Ma, Y.-Q.; Qiu, L.-L.; Fang, J.-X. Biphenyl-Based Diaminophosphine Oxides as Air-Stable Preligands for the Nickel-Catalyzed Kumada-Tamao-Corriu Coupling of Deactivated Aryl Chlorides, Fluorides, and Tosylates. Chem. Eur. J. 2012, 18, 446-450. [CrossRef]

59. Martinez, J.; Laur, J. Active Esters of Formic Acid as Useful Formylating Agents: Improvements in the Synthesis of Formyl-Amino Acid Esters, N- $\alpha$-Formyl-Met-Leu-Phe-OH, and Formyl-Met-Lys-Pro-Arg, a Phagocytosis Stimulating Peptide. Synthesis 1982, 1982, 979-981. [CrossRef]

60. Liu, X.; Cai, T.-C.; Guo, D.; Wang, B.-B.; Ying, S.; Wang, H.; Tang, S.; Shen, Q.; Gui, Q.-W. Electrochemical Synthesis of Symmetrical Benzidines through Dehydrogenative Cross-Coupling Reaction. Tetrahedron Lett. 2021, 70, 153021. [CrossRef]

61. Ibrahim, D.H.; Dunet, J.; Robert, F.; Landais, Y. Oxidation of 1-Arylcyclohexa-2,5-Dienes and Subsequent Double Michael Addition. A Rapid Access to the Büchi Ketone and the Pentacyclic Core of Aspidosperma Alkaloids. Heterocycles 2018, 97, 459-477. [CrossRef]

62. Koguchi, Y.; Kohno, J.; Nishio, M.; Takahashi, K.; Okuda, T.; Ohnuki, T.; Komatsubara, S. TMC-95A, B, C, and D, Novel Proteasome Inhibitors Produced by Apiospora Montagnei Sacc. TC 1093 Taxonomy, Production, Isolation, and Biological Activities. J. Antibiot. 2000, 53, 105-109. [CrossRef]

63. Wencel-Delord, J.; Panossian, A.; Leroux, F.R.; Colobert, F. Recent Advances and New Concepts for the Synthesis of Axially Stereoenriched Biaryls. Chem. Soc. Rev. 2015, 44, 3418-3430. [CrossRef]

64. Uozumi, Y.; Hayashi, T. Catalytic Asymmetric Synthesis of Optically Active 2-Alkanols via Hydrosilylation of 1-Alkenes with a Chiral Monophosphine-Palladium Catalyst. J. Am. Chem. Soc. 1991, 113, 9887-9888. [CrossRef]

65. Smrčina, M.; Lorenc, M.; Hanuš, V.; Kočovský, P. A Facile Synthesis of 2-Amino-2'-Hydroxy-1,1'-Binaphthyl and 2,2'-Diamino1,1'-Binaphthyl by Oxidative Coupling Using Copper(II) Chloride. Synlett 1991, 1991, 231-232. [CrossRef]

66. Gavrilov, K.N.; Shiryaev, A.A.; Zheglov, S.V.; Bochelyuk, M.S.; Chuchelkin, I.V.; Tafeenko, V.A.; Chernyshev, V.V.; Zamilatskov, I.A.; Mikhel, I.S. NOBIN-Based Chiral Phosphite-Type Ligands and Their Application in Asymmetric Catalysis. Tetrahedron Lett. 2015, 56, 4756-4761. [CrossRef]

67. Zhang, D.; Wang, Q. Palladium Catalysed Asymmetric Suzuki-Miyaura Coupling Reactions to Axially Chiral Biaryl Compounds: Chiral Ligands and Recent Advances. Coord. Chem. Rev. 2015, 286, 1-16. [CrossRef]

68. Wang, G.; Shi, Q.; Hu, W.; Chen, T.; Guo, Y.; Hu, Z.; Gong, M.; Guo, J.; Wei, D.; Fu, Z.; et al. Organocatalytic Asymmetric N-Sulfonyl Amide C-N Bond Activation to Access Axially Chiral Biaryl Amino Acids. Nat. Commun. 2020, 11, 946. [CrossRef] [PubMed]

69. Benmahdjoub, S.; Ibrahim, N.; Benmerad, B.; Alami, M.; Messaoudi, S. One-Pot Assembly of Unsymmetrical Biaryl Thioglycosides through Chemoselective Palladium-Catalyzed Three-Component Tandem Reaction. Org. Lett. 2018, 20, 4067-4071. [CrossRef]

70. Yamamura, S.; Nishiyama, S. Anodic Oxidation of Phenols Towards the Synthesis of Bioactive Natural Products. Synlett 2002, 2002, 533-543. [CrossRef]

71. Kirste, A.; Schnakenburg, G.; Stecker, F.; Fischer, A.; Waldvogel, S.R. Anodic Phenol-Arene Cross-Coupling Reaction on Boron-Doped Diamond Electrodes. Angew. Chem. Int. Ed. 2010, 49, 971-975. [CrossRef] [PubMed]

72. Kirste, A.; Elsler, B.; Schnakenburg, G.; Waldvogel, S.R. Efficient Anodic and Direct Phenol-Arene C,C Cross-Coupling: The Benign Role of Water or Methanol. J. Am. Chem. Soc. 2012, 134, 3571-3576. [CrossRef] 
73. Kashiwagi, T.; Elsler, B.; Waldvogel, S.R.; Fuchigami, T.; Atobe, M. Reaction Condition Screening by Using Electrochemical Microreactor: Application to Anodic Phenol-Arene C,C Cross-Coupling Reaction in High Acceptor Number Media. J. Electrochem. Soc. 2013, 160, G3058. [CrossRef]

74. Simcik, M.F. Aquatic Processes and Systems in Perspective. Global Transport and Fate of Perfluorochemicals. J. Environ. Monit. 2005, 7, 759-763. [CrossRef]

75. Mayer, U.; Gutmann, V.; Gerger, W. The Acceptor Number-A Quantitative Empirical Parameter for the Electrophilic Properties of Solvents. Mon. Chem. 1975, 106, 1235-1257. [CrossRef]

76. Cozens, F.L.; Kanagasabapathy, V.M.; McClelland, R.A.; Steenken, S. Lifetimes and UV-Visible Absorption Spectra of Benzyl, Phenethyl, and Cumyl Carbocations and Corresponding Vinyl Cations. A Laser Flash Photolysis Study. Can. J. Chem. 1999, 77, 2069-2082. [CrossRef]

77. Dahms, B.; Franke, R.; Waldvogel, S.R. Metal- and Reagent-Free Anodic Dehydrogenative Cross-Coupling of Naphthylamines with Phenols. ChemElectroChem 2018, 5, 1249-1252. [CrossRef]

78. Yasukouchi, K.; Taniguchi, I.; Yamaguchi, H.; Yokoyama, M.; Murasaki, M. Anodic Cyclization of Di-2-Naphthylamine. Chem. Lett. 1979, 8, 1167-1170. [CrossRef]

79. Lips, S.; Frontana-Uribe, B.A.; Dörr, M.; Schollmeyer, D.; Franke, R.; Waldvogel, S.R. Metal- and Reagent-Free Anodic C-C Cross-Coupling of Phenols with Benzofurans Leading to a Furan Metathesis. Chem. Eur. J. 2018, 24, 6057-6061. [CrossRef]

80. Miao, Y.; Hu, Y.; Yang, J.; Liu, T.; Sun, J.; Wang, X. Natural Source, Bioactivity and Synthesis of Benzofuran Derivatives. RSC Adv. 2019, 9, 27510-27540. [CrossRef]

81. Khanam, H. Shamsuzzaman Bioactive Benzofuran Derivatives: A Review. Eur. J. Med. Chem. 2015, 97, 483-504. [CrossRef]

82. Khodarahmi, G.; Asadi, P.; Hassanzadeh, F.; Khodarahmi, E. Benzofuran as a Promising Scaffold for the Synthesis of Antimicrobial and Antibreast Cancer Agents: A Review. J. Res. Med. Sci. 2015, 20, 1094-1104. [CrossRef]

83. Wang, Q.-Q.; Jiang, Y.-Y.; Zeng, C.-C.; Sun, B.-G. Electrocatalytic Synthesis of Non-Symmetric Biphenols Mediated by Tri(pBromophenyl)Amine: Selective Oxidative Cross-Coupling of Different Phenols and Naphthols. Chin. J. Chem. 2019, 37, 352-358. [CrossRef]

84. Luo, M.-J.; Li, Y.; Ouyang, X.-H.; Li, J.-H.; He, D.-L. Electrochemical Dehydrogenative Cross-Coupling of Two Anilines: Facile Synthesis of Unsymmetrical Biaryls. Chem. Commun. 2020, 56, 2707-2710. [CrossRef]

85. Vettorazzi, N.; Silber, J.J.; Sereno, L. Anodic Oxidation of 1-Naphthylamine in Acetonitrile. J. Electroanal. Chem. Interfacial Electrochem. 1981, 125, 459-475. [CrossRef]

86. Feng, P.; Ma, G.; Chen, X.; Wu, X.; Lin, L.; Liu, P.; Chen, T. Electrooxidative and Regioselective C-H Azolation of Phenol and Aniline Derivatives. Angew. Chem. Int. Ed. 2019, 58, 8400-8404. [CrossRef] [PubMed]

87. Jabir, N.R.; Firoz, C.K.; Bhushan, A.; Tabrez, S.; Kamal, M.A. The Use of Azoles Containing Natural Products in Cancer Prevention and Treatment: An Overview. Anti Cancer Agents Med. Chem. 2018, 18, 6-14. [CrossRef]

88. Fontana, G. Current Bioactive Azole-Containing Natural Products. Curr. Bioact. Compd. 2010, 6, 284-308. [CrossRef]

89. Gao, H.; Shreeve, J.M. Azole-Based Energetic Salts. Chem. Rev. 2011, 111, 7377-7436. [CrossRef]

90. Lips, S.; Schollmeyer, D.; Franke, R.; Waldvogel, S.R. Regioselective Metal- and Reagent-Free Arylation of Benzothiophenes by Dehydrogenative Electrosynthesis. Angew. Chem. Int. Ed. 2018, 57, 13325-13329. [CrossRef] [PubMed]

91. Wu, J.; Zhou, Y.; Zhou, Y.; Chiang, C.-W.; Lei, A. Electro-Oxidative C(Sp3)-H Amination of Azoles via Intermolecular Oxidative $\mathrm{C}(\mathrm{Sp} 3)-\mathrm{H} / \mathrm{N}-\mathrm{H}$ Cross-Coupling. ACS Catal. 2017, 7, 8320-8323. [CrossRef]

92. Tang, H.; Smolders, S.; Li, Y.; Vos, D.D.; Vercammen, J. Electro-Oxidative C(Sp2)-H/O-H Cross-Dehydrogenative Coupling of Phenols and Tertiary Anilines for Diaryl Ether Formation. Catal. Sci. Technol. 2021, 11, 3925-3930. [CrossRef]

93. Bedos-Belval, F.; Rouch, A.; Vanucci-Bacqué, C.; Baltas, M. Diaryl Ether Derivatives as Anticancer Agents-A Review. Med. Chem. Commun. 2012, 3, 1356-1372. [CrossRef]

94. Lee, C.-C.; Leung, M.; Lee, P.-Y.; Chiu, T.-L.; Lee, J.-H.; Liu, C.; Chou, P.-T. Synthesis and Properties of Oxygen-Linked NPhenylcarbazole Dendrimers. Macromolecules 2012, 45, 751-765. [CrossRef]

95. Roughley, S.D.; Jordan, A.M. The Medicinal Chemist's Toolbox: An Analysis of Reactions Used in the Pursuit of Drug Candidates. J. Med. Chem. 2011, 54, 3451-3479. [CrossRef]

96. Osa, T.; Kashiwagi, Y.; Yanagisawa, Y.; Bobbitt, J.M. Enantioselective, electrocatalytic oxidative coupling of naphthol, naphthyl ether and phenanthrol on a TEMPO-modified graphite felt electrode in the presence of (-)-sparteine. J. Chem. Soc. Chem. Commun. 1994, 21, 2535-2537. [CrossRef]

97. Pletcher, D. Electrolysis Cells for Laboratory Organic Synthesis. Curr. Opin. Electrochem. 2020, 24, 1-5. [CrossRef]

98. Noël, T.; Cao, Y.; Laudadio, G. The Fundamentals Behind the Use of Flow Reactors in Electrochemistry. Acc. Chem. Res. 2019, 52, 2858-2869. [CrossRef] [PubMed]

99. Elsherbini, M.; Wirth, T. Electroorganic Synthesis under Flow Conditions. Acc. Chem. Res. 2019, 52, 3287-3296. [CrossRef] [PubMed]

100. Marino, D.D.; Stöckmann, D.; Kriescher, S.; Stiefel, S.; Wessling, M. Electrochemical Depolymerisation of Lignin in a Deep Eutectic Solvent. Green Chem. 2016, 18, 6021-6028. [CrossRef]

101. Nkuku, C.A.; LeSuer, R.J. Electrochemistry in Deep Eutectic Solvents. J. Phys. Chem. B 2007, 111, 13271-13277. [CrossRef] 